\title{
Leandro Vieira e o samba catártico nas manifestações políticas
}

\section{Marcelo Campos ${ }^{1}$}

Resumo: Os carnavais mais recentes da Estação Primeira de Mangueira, sob a criação artística do carnavalesco Leandro Vieira, vêm se destacando pelo viés políticos, ao defender pautas contrárias ao racismo, à LGBTQfobia, à invisibilidade de heróis brasileiros que, segundo o enredo de 2019, não estão no retrato. O texto aborda essa concepção político-revolucionária que não começou agora, mas, antes, em diversos momentos da história do samba e das escolas de samba do Rio de Janeiro.

Palavras-chave: carnaval, Leandro Vieira, Estação Primeira de Mangueira, racismo, LGBTQfobia.

Abstract: The most recent carnivals at Estação Primeira de Mangueira, under the artistic creation of artist Leandro Vieira, have stood out for their political bias, in defending agendas contrary to racism, LGBTQphobia, the invisibility of Brazilian heroes who, according to the 2019 plot, did not are in the picture. The text addresses this political-revolutionary conception that did not start now, but, rather, at different times in the history of samba and the samba schools of Rio de Janeiro.

Keywords: Carnival, Leandro Vieira, Estação Primeira de Mangueira, racism, LGBTQphobia.

1 Professor Adjunto do Departamento de Teoria e História da Arte. Doutor em Artes pelo PPGAV/UFRJ. Mestre em Antropologia da Arte pelo PPGAV/UFRJ. Curador do Museu de Arte do Rio.

E-mail: campos.marcelo@gmail.com; ORCID: https://orcid.org/0000-0001-6011-5318;

ISN: http://www.isni.org/isni/0000000071155713; Instituição filial: Universidade do Estado do Rio de Janeiro; Cidade: Rio de Janeiro; País: Brasil 
"Exú nas escolas", Jesus na favela, frases que reverberam, hoje, em contextos de empoderamento étnico-raciais e de luta contra a intolerância religiosa. Exú nas escolas é um dos versos da canção de Kiku Dinucci e do rapper Edgar gravada por Elza Soares - a mulher do fim do mundo - cantora que, em sua biografia, representa parte das lutas que envolvem gênero e raça no Brasil. O que nos faz, então, rever e clamar por frases e versos cantados por quem foi considerada a cantora do milênio, em votação da renomada Rádio BBC de Londres? O que pensar sobre a presença de Exu na educação de crianças, jovens e adultos em um país invadido por europeus, cujas religiões de matrizes africanas acumulam trajetórias de perseguição, criminalização e racismo?

Jesus na favela nos direciona a outras searas de reflexão. Em reportagem de 1977, o Jornal do Brasil estampava o título "Jesus nasceu na favela". O texto desenvolvia análise sobre a pujança das atribuições artísticas e sociais dos brasileiros, nas artes, no futebol, na música. Discorria na afirmação de que "o maior homem do mundo", Jesus, havia nascido em Nazaré, quase uma favela. Portanto, seguindo a referida análise, Jesus seria, também, um favelado. O que nos remete a outros momentos da literatura e da música em afirmações, nas quais Cristo, por exemplo, havia nascido na Bahia ou em Belém do Pará, nas afirmações de Oswald de Andrade. Ou, ainda, na canção Gesù bambino, composta pelo italiano Lucio Dalla e que ganhou versão de Chico Buarque (Minha história), alcançando enorme sucesso. Na canção da década de 1970, Jesus nasce de mãe prostituta e pai marinheiro e pescador. Amigo de ladrões e amantes, frequenta bares, grita, bebe, briga. Temos, assim, certa humanização e periferização da figura de Cristo, aproximando-o dos pobres, da miséria, da fome.

Toda essa digressão se fez necessária, aqui, para enfrentarmos os usos das imagens de Cristo pelo carnaval de Leandro Vieira. Fato que nos faz renovar a compreensão do samba e do carnaval como constituídos por momentos de grandes criações artísticas, obras-primas, talvez, e de bandeiras e desabafos críticos entoados, ecoados, para muito além das fronteiras de uma cidade. Tais efeitos passaram a ser sentidos nos desfiles da Mangueira de Leandro Vieira, em que tradição e luta, quilombismo e decolonialidade se alinharam em rara aparição artística.

Arte e carnaval, arte carnavalesca, arte. Com a secular ampliação dos sentidos da arte, talvez contemporânea à data de surgimento dos desfiles das Escolas de Samba, nas primeiras décadas do século XX, a arte carnavalesca se desenvolveu em franca exibição de capacidade criativa e inventiva. Para além da capacitação de escultures, ferreiros, 
bordadeiras, o carnaval reinventa, a cada ano, as máscaras da cultura popular, as fantasias, cria alegorias e adereços, (verdadeiras esculturas), usa materiais de descarte, agiganta a escala e os movimentos de carros alegóricos, interpreta um assunto (enredo) em figurinos, personagens, visualidades e conduz a maior de todas as artes, a invenção da alegria, "prova dos nove", como nos alertou o manifesto modernista de Oswald de Andrade. A questão que se coloca é como fazer com que tudo isso se amalgame? Como tornar uma história decodificável pelo público a ponto de fazer nossas tristezas balançarem, transformando um desfile, até, num ato político? Esta utopia foi, algumas vezes, alcançada pelos carnavais campeões de Leandro Vieira.

Nascido no Rio de Janeiro, formado pela Belas Artes da UFRJ, na llha do Governador, Leandro Vieira inicia sua trajetória de carnavalesco na Caprichosos de Pilares, em 2015; um ano depois, sagra-se campeão com o enredo "A menina dos olhos de Oyá", em homenagem à cantora Maria Bethânia, na Estação Primeira de Mangueira. Segundo o próprio Vieira, sua experiência nos barracões das escolas de samba, adquirida desde 2007, atravessou diversas atuações, como, figurinista, além de assistente de carnavalesco. Com isso, o que se vê nos últimos anos, é a atuação de um artista que se destaca na atualização dos desfiles, seja no renovado olhar sobre o passado, seja no uso de novos recursos dramatúrgicos para o espetáculo, como a inserção de pautas políticas e críticas mais diretas à história do Brasil.

O olhar de Leandro Vieira renova a relação com os criadores no âmbito da arte contemporânea. Vieira observa desde a história da escultura no Brasil, trazendo referências como o Templo de Oxalá, de Rubem Valentim, ou o Monumento às Bandeiras, obra pública de Victor Brecheret, pichada pelos movimentos sociais que criticam e denunciam os bandeirantes como assassinos de comunidades negras e indígenas. Esses gestos tornam-se gestos da arte que, há algum tempo, lança mão de signos deslocados, reincorporados para que outros significados possam se agregar aos originais, cujo exemplo mais óbvio seriam os ready mades de Marcel Duchamp.

Assim, o carnavalesco propõe a revisão da história, carregando nas tintas da reparação histórica. Há sangues atrás dos heróis do enredo de 2019, "A história que a história não conta". Ali, o carnaval conferia que a liberdade veio do povo, desde personagens como o Dragão do Mar, pescador do Ceará que veio ao Rio de jangada para exigir direitos ao então Presidente, Getúlio Vargas; e os heróis revolucionários da ditadura militar. Enquanto isso, o samba se aproxima, nos seduz, nos chamando 
de "meu nego", "meu dengo", e dando aula de história, indo e voltando no tempo, em transversalidades tão requeridas, hoje, pela academia. $\mathrm{E}$ segue ensinando, criando intertextualidades: "tira a poeira dos porões", verso que refaz Ary Barroso, em antiga canção que conclamava, "Tira a mãe preta do cerrado". Observa-se, então, a gíria, o falar popular "tira a poeira" o que nos remete a outro termo, também cantado em samba, "sacode a poeira", e nos estimula: siga em frente, vai viver. Os livros, mesmo com toda utopia iluminista, apagaram versos, rasgaram as páginas da história em atitude violenta, tirana, trocando nossa cara de índio, de Cariri, por feições branqueadas, desde o romance Iracema, de José de Alencar, à subalternização racial em Monteiro Lobato. O próprio rosto de Jesus Cristo foi branqueado em uma história oficial. Portanto, nossas arvores genealógicas sempre encontraram barreiras, pois as mesmas se interrompem quando encontram os grupos indígenas dizimados, ou africanos em valongos, cemitérios de escravizados. Mas, ainda se abrem esperanças, vocação de todo samba, em afirmações como, "chegou a vez de ouvir". Disponibiliza-se a escuta, abrem-se os lugares de fala, aos pretos e pretas, aos indígenas, calados por invasões, necropolíticas, epistemicídios, "um país que não está nos retratos" e cuja liberdade não veio "das mãos de Isabel", mas dos caboclos, os que nos defumam com charutos nas umbandas, angolas, e os que lutaram nas revoltas de 2 de julho. $\mathrm{Na}$ junção de negros e indígenas, naquilo que Marcio Goldman chamou de contra-mestiçagem, o branco está fora da fábula das três raças na formação do Brasil. E isto é simples de entender, basta entrarmos na Casa das Minas, observarmos os bumbás do Maranhão, de Pernambuco para presenciarmos as junções de forças pretas e indígenas.

Com o samba, já clássico, "História para ninar gente grande", o que vimos na avenida foi um desfile (todo) obra de arte. Um samba que vira hino de protesto, como os Heróis da liberdade, do Império Serrano, mas que, ao mesmo tempo, tem "feitio de oração", reversão comum pelo Brasil, como acontecera com Sorriso negro, samba de Dona Ivone Lara, hoje entoado em missas das igrejas de Nossa Senhora do Rosário dos Pretos. O desfile de 2019 de Vieira, então, em sua totalidade, tornou-se uma bandeira, em nome de índios, negros e pobres, substituindo o "ordem e progresso" da bandeira nacional. As mulheres invisibilizadas pela história são recriadas, já que seus retratos não existem, como Luisa Mahim, Dandara. E, por outro lado, Vieira sublinhou outros heróis, como Leci Brandão e Jamelão, dois baluartes da Mangueira.

O samba sempre acompanhou diversas revoluções, desde os "cantos dos escravos", gravados por Clementina de Jesus, Tia Doca... E, ainda antes, 
em gravações dos anos 1930 feitas por Heitor dos Prazeres, em louvor aos orixás, Oxum, e ainda todas as frases de revolta no empoderamento feminino de Dona Ivone Lara, ao responder a um possível amor desfeito "a vida foi em frente, você, simplesmente, não viu que ficou pra trás", canções escritas e cantadas em momentos onde a separação, antes da lei do divórcio, deixava às mulheres uma pecha de imoralidade. Sem falar nos ambientes boêmios, livres, em que as compositoras enfrentavam, também, o machismo dos próprios sambistas. E se garantiam, como nos versos da Jovelina Pérola Negra: "eu seguro o pagode, não deixo cair, sem vacilar", assumindo, para si, o protagonismo, o empoderamento, o controle da situação, antes e, ainda hoje, dominada pela presença do homem. Também lembremos do que Leci Brandão, a mesma que viveu o personagem de Dandara, mulher de Zumbi dos Palmares no carnaval de Leandro Vieira, quando "mandava a rela", parafraseando a gíria, ao afirmar "Mulher, deixa de bobeira, mulata nunca foi uma profissão".

Tratar, também, de crítica social, protesto, desfiles-passeatas renderia laudas e laudas. Heróis da liberdade do Império Serrano, Zumbi dos Palmares, do Salgueiro, Kizomba, festa da raça, de Vila Isabel, a crítica e o humor da Caprichosos de Pilares ou da São Clemente, os hinos recentes da Paraíso do Tuiutí, "Meu Deus, Meu Deus, se eu chorar, não leve a mal, pela luz do candeeiro, liberte o cativeiro social". Com isso, desfiles fazem, refazem, atualizam, ritualizam feridas sociais, traumas que, na avenida, passam a ter um rito de cura, uma catarse.

Heróis da liberdade, um exemplo de 1969, usava a metáfora da ditadura em enredo que tratava de escravidão e pedia, por exemplo, "o fim da tirania", abrindo vozes para os trechos do hino da independência "já raiou a liberdade/liberdade já raiou".

A religiosidade, a fé, a alegria das ruas, as passeatas de protesto, as notícias de jornal, muitas são as referências que vemos passar no carnaval de Leandro Vieira. Contudo, há que se destacar a capacidade de se fazer história bem antes do carnaval, colocando o enredo, o assunto, nas rodas de conversa, protesto e discussão, assim foi com Maria Bethânia, a menina dos olhos de Oyá, com Marielle Franco, em história para ninar gente grande e se mantém com "a verdade vos fará livre", em que Jesus Cristo renasce negro, no Morro da Mangueira.

E ouvimos os estivadores e lavadeiras do Império Serrano nos aconselhar em clamor: "Samba/Oh Samba/Tem a sua primazia de gozar da felicidade/Samba, meu samba/Presta essa homenagem/Aos heróis da liberdade". Felicidade e resistência, ensinamentos raros que a arte pode 
ouvir dos sambas e das manifestações das ruas, vozes que parecem discrepantes, mas, que, em consonância, fazem do dia a dia da pobreza e das lutas antirracistas e democráticas algo a ser empunhado como alegoria, bandeira, ainda que a política surda negue tal possibilidade e se amedronte por uma possível revolução, cuja reparação histórica da presença de "índios, negros e pobres", escritos na bandeira do desfile da Mangueira de 2019, faça do canto e do grito algo que coloque as palavras "ordem e progresso" em plena incapacidade.

São verde e rosa as multidões. 